\title{
Budist Uygurlarda Yétiken Takımyıldızı inancı
}

\section{Hasan İsí1}

\begin{abstract}
APA: İsi, H. (2020). Budist Uygurlarda Yétiken Takımyıldızı inancı. RumeliDE Dil ve Edebiyat
\end{abstract} Araşturmalar Dergisi, (Ö7), 206-223. DOI: 10.29000/rumelide.808463.

\section{$\ddot{\mathbf{O} z}$}

Büyükayı Takımyıldızı, insanlık tarihi boyunca birçok medeniyetin mitolojik ve astrolojik inanç sistemleri içerisinde dinî ve din dışı değerlere sahip olmuştur. Bu takımyıldızı, Türk düşünce sistemi içerisinde hem yazılı metinler hem de sözlü kaynaklar vasıtasıyla görülmektedir. Bu çalışma, Büyükayı Takımyıldızı özelinde Budist Uygurlarda Yétiken adıyla görülen inanca dayalı uygulamaları ele almaktadır. Bu uygulamalar, Eski Uygur Türkçesine 14. yüzyılda Çinceden çevrilen ve Çin düşünce sistemi içerisindeki Taoist ve Tantrik fikirleri yansitan Yétiken Sūtra adlı eserde görülmektedir. Bu yönüyle eldeki çalışma, Yétiken Sūtra içerisinde yer alan Taoist ve Budist fikirleri ortaya koyma amacından ileri gelmektedir. Ağırlıklı olarak 14. yüzylla tarihlenen Uygur Budizmi eserleri içerisinde yer alan Yétiken Sütra, bünyesinde hem Taoizm hem de Tibet Budizmi’ne dayalı unsurları barındırmaktadır. Bu unsurlar, eldeki yazı içerisinde ağırlıklı olarak Çin Budizmi içerisindeki Taoist fikirler olup Tantrik Budizm’in etkilerini de yansıtan uygulamaları da içermektedir. Bu uygulamalar, takımyıldızlara ilahlık yükleme, muskalar, ilahlara yakarış, yemek sunuları gibi Taoist uygulamalar ile Tibet ve Çin Budizmi içerisinde öneme sahip Buda ve Bodisattva kişiliklerini oluşturmaktadır. Ayrıca, Eski Uygurca Yétiken Sūtra içerisinde hem Taoizm hem de Tibet Budizmi ile de ortaklaşan özellikler de söz konusudur. Bunlar arasında uzun yaşama sahip olma, hastalık ve sıkıntılardan kurtulma, işinde terfi etme gibi ortaklıklar yer almaktadır. Bu doğrultuda, Yétiken Sütra Budist Uygurların Çin Budizmi kaynaklı dinî etkileri göstermesi bakımından önem arz etmektedir.

Anahtar kelimeler: Büyükayı Takımyıldızı, Yétiken, Beidou, Tantrik Budizm, Eski Uygurlar

\section{The Yétiken Constellation belief in Buddhist Uyghurs}

\begin{abstract}
The Ursa Major Constellation has religious and non-religious values within the mythological and astrological belief systems of many civilizations throughout human history. This constellation is seen through both written texts and oral sources within the Turkish thought system. This study deals with belief-based practices as Ursa Major Constellation in the seen Yétiken in Buddhist Uyghurs. These practices can be seen in Yétiken Sūtra, which from Chinese into Old Uyghur Turkic translated in the 14th century and reflects Taoist and Tantric ideas within the Chinese thought system. In this respect, this article comes from the aim of revealing the appearance of Taoist and Tantric ideas in Yétiken Sūtra. Yétiken Sūtra, which is among the Uyghur Buddhism works that are mostly dated to the 14th century, includes elements based on both Taoism and Tibetan Buddhism. These elements are mainly Taoist ideas in Chinese Buddhism in the this article and also include practices that reflect the effects of Tantric Buddhism. These practices constitute Buddha and Bodhisattva personalities that are important in Tibetan and Chinese Buddhism, as well
\end{abstract}

Dr.,Bağımsız Araştırmacı (Ankara, Türkiye), hasanisi21@yahoo.com.tr, ORCID ID: oooo-ooo1-7269-3596 [Makale kayit tarihi: 23.07.2020-kabul tarihi: 20.10.2020; DOI: 10.29000/rumelide.808463] 
as Taoist practices such as see constellations as gods, amulets, clams and food offerings. There are also features common to both Taoism and Tibetan Buddhism within the Old Uyghur Yétiken Sūtra. These include partnerships such as having a long life, getting rid of diseases and troubles, and promoting at work. In this respect, Yétiken Sütra is important in terms of showing Buddhist Uyghurs religious effects originating from Chinese Buddhism.

Keywords: Ursa Major Constellation, Yétiken, Beidou, Tantric Buddhism, Old Uyghurs

\section{Giriş}

Orta ve Doğu Asya düşünce sistemleri içerisinde göksel varlıklara olan inanç, Çin Budizmi temelli dinî yapılar içerisinde görülmektedir. Yaşanılan coğrafya üzerinde kültürel ve dinî etkileşim ürünü olarak karşımıza çıkan Büyükayı Takımyıldızı, başta Çin olmak üzere, Kore, Japon, Moğol ve Türk gibi kültürlerde çeşitli ritüel biçimleri ile görülmektedir.

Ursa Major veya Büyükayı Takımyıldızı, modern astronomların gökyüzünü böldüğü 88 takımyıldızı unsurundan biridir. Bu takımyıldızı en yaygın bilinen yıldız oluşumlarından biridir. Big Dipper, ayının gövdesini ve kuyruğunu oluşturur. Diğer yıldızlar ayının uzun burnunu ve bacaklarını meydana getirir. Yunan mitolojisinde Büyükayı Hera tarafından bir ayıya dönüştürülen Callisto'yu temsil eder. Callisto'nun oğlu Arcas Hera'yı öldürmeye çalışır ve Zeus olaya müdahale ederek onları gökyüzüne koyar. Mitolojik açıdan Greklere dayandırılan bu takımyıldızı, Latincede Greater Bear olarak bilinen Büyükayı yıldızının orijinal ismidir. Romalılar bu yıldızı, Arctos ya da Ursa olarak adlandırmaktadır. Batlamyus, bu takımyıldızını gökyüzünde özellikle kuzey yönünde en parlak yıldız grubu olarak adlandırmıştır. Hintliler, Yedi Yıldız'dan oluşan Büyükayı Takımyldızına Yedi Bilge anlamında rishi adını vermiştir (https://osr.org/tr/takimyildizi/ursamajor/; https://www.britannica.com/place/Ursa-Major Erişim Tarihi: 14.07.2020).

Mitolojik anlatılar içerisinde hakkında bilgi sahibi olduğumuz Büyükayı Takımyıldızı, ayrıca gece vakti hem kara hem denizde giden yolcular, kervanlar ve çobanlar için yol gösterici olması bakımından önemlidir (https://thenewkorea.wordpress.com/2015/09/17/the-seven-stars-of-the-north-5/Erişim Tarihi: 14.07.2020).

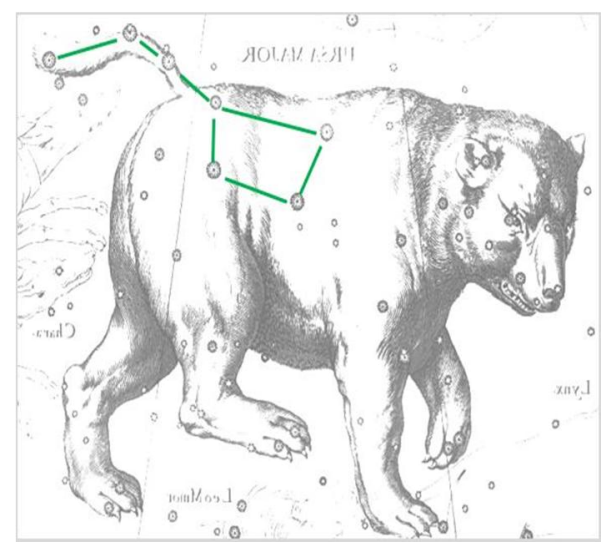

Resim 1: Büyükayı Takımyıldız’na İlham Veren Ayı Sureti (http://www.futura-sciences.us/dico/d/spaceconstellation-ursa-major-50005604/ Erişim Tarihi: 14.07.2020). 


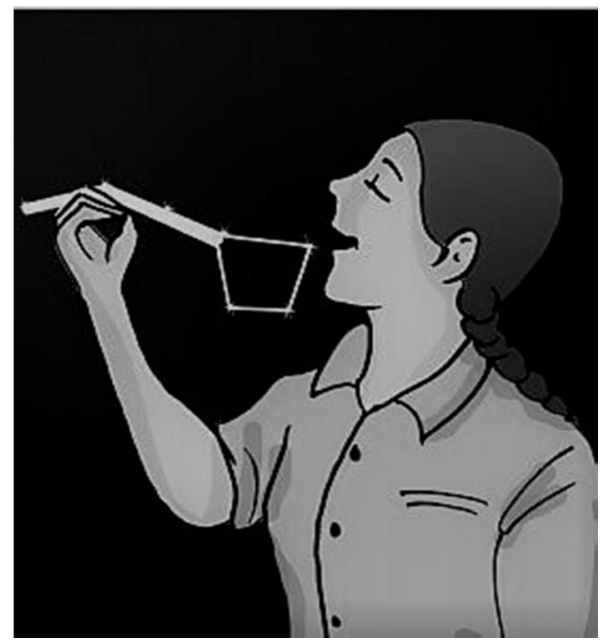

Resim 2: Uzakdoğu ve Orta Asya'da Kuzey Kepçe Yıldızı Adlandırmasına Dayanak Olan Kepçe Figürü (http://aven.amritalearning.com/index.php?sub=101\&brch=299\&sim=1515\&cnt=3513 Erişim Tarihi: 14.07.2020).

Resim 1 ve Resim 2'de, bu Yedi Yıldız’ın birleşimi ile kepçe şeklinin ortaya çıtığı görülmektedir. Ayı sembolü ile gösterilen ve ayının kuyruk ve sırt bölümü içerisinde ortaya çıkan bu görünüm, özellikle, Doğu Asya'da Kuzey Kepçe Yıldızı (Northern Dipper) adlandırmasına dayanak oluşturmaktadır. Bu bilgi, Çin Budizmi içerisinde bu takımyıldızına olan inancı yansıtan Běi dǒu 北斗 (Taishō 1307) metni ile de görülmektedir.

Budist Uygur kültürüne kaynaklık etmesi bakımından Asya kültürleri içerisinde bu takımyıldızının başta Çin, Kore ve Japonya gibi ülkeler yanında Moğol ülkesinde de karşılık bulduğu görülmektedir. Çin astrolojisinde Beidou olarak bilinen Büyükayı Takımyıldızı önemli bir yere sahiptir. Büyükayı Takımyıldızı'nın insan kaderini belirleyen yönü, bu takımyldızına ibadet etmeyi popüler kılmıştır. Büyükayı Takımyıldızı'na tapma, Çin tarihinin erken dönemlerinde görülür ve bu inanç, Budizm’in Çin'e geldiği dönemde büyük bir yaygınlığa sahip olmuştur (Sørensen, 2011a: 230). Büyükayı kültü, Japonya'ya Shingon Budizmi yoluyla tanıtılmıştır. Japonya'da Büyükayı Takımyıldızı, Çin etkisi ile zamanla bir inanç hâline gelmiştir (Payne, 2016: 293). Japonya'da gökyüzü ile ilgili Budist büyüler, Onmyōdō denilen Japon ezoterik kozmolojisinin Taoist etkilerle karşılaşması sonucu gelişen düşünce sisteminden izler taşımaktadır. Taoist karakter gösteren Büyükayı'nın Yedi Yıldız’ı, Tang Hanedanlığı dönemi Çin’inde görülen "uzun yaşam" vaadiyle kendisini sūtralar ve bu sūtralar içerisinde yer alan diyagram ve muskalarla göstermektedir (Kotyk, 2018: 54). Büyükayı Takımyıldızı, Kore'de önemli ilahlardan biridir. Yedi Yıldız kültü, Kore'de Tibet Budizmi ile görülmektedir. Kökeni, Tang Hanedanlığı dönemine giden bu inanç, Kore Budizmi’nde 8. yüzyıldan itibaren etkisini göstermektedir. Kore Budizmi’nde Yedi Yıldız kültü ile ilgili ritüellere bakıldığında, Erken Kore döneminin üç krallı̆̆ından biri olan Koguryŏ ülkesinde Büyükayı Takımyıldızına ait duvar resimleri bulunmuştur. 13. yüzyılın sonlarında Yedi Yıldız ilahları ile ilgili birçok ritüel, özellikle çocukların yaşam uzunluğunu kontrol etmede popüler duruma gelmiştir (Buswell ve Lopez, 2014: 102). Astrolojik uygulamalar, Moğollarda genellikle yeni doğacak bir çocuğun kötü doğumdan ve kötü gezegen etkilerine denk gelmemesi için kullanılmıştır (Atwood, 2004: 26). Moğollar arasında Büyükayı Takımyldızı, "Yedi Yaşlı Adam" anlamında dolugan ebügen olarak adlandırılır. Bu terim, Moğollar için kaderi tayin eden denetçi ilahlar demektir. Moğol toplumu içerisinde bu ilahlara yapılan yakarış, Çin'de olduğu gibi yemek sunuları gibi uygulamalarla gerçekleşmektedir. "Yedi Yaşlı Adam" figürü, 
Moğollarda avlanma, iyi bir ata sahip olma, iyi bir lider olma gibi amaçlar yanında Hormuzta Tanrı ile birlikte olma, Otuz Üç Tanrı Cenneti’nde olma, şeytan ve kötü ruhlardan kurtulma gibi hedefler içermektedir. Ayrıca, genel olarak Moğol toplumunda yerel dinî uygulamalar hem Büyükayı hem de Sanskritçe kökenli yıldızlara bereket, sağlık, uzun yaşam getirici gözüyle bakılmasından dolayı popüler bir durumdadır (Heissig, 1980: 81, 82).

Türk düşünce sistemi içerisinde ise Büyükayı Takımyıldızı, hem dinî hem de din dışı yöne sahiptir.

Yedi Yıldız’dan oluşan Büyükayı Takımyıldızı, gökyüzünde dairevi dolaştığı için bazı Türk kavimleri yıllık takvimlerini de Yedi Han'a göre tayin ederler. Bazı mitolojik inançlara, özellikle de bozkır Türklerinin inancına göre, Küçükayı Takımyıldızı bir arabayı çeken iki at, Büyükayı Takımyıldızı ise bu iki atı kovalayan yedi kurt olarak bilinir. Sembolik şekilde kurt ve atlara dönüştürülen Büyükayı ve Küçükayı Takımyıldızları, diğer Türk kavimlerinde hırsızlar ve at simgesine dönüștürülmüsstür. Yétiken takımyıldızının hükümdarın arabası olup Kutup Yıldızı'na bağlı bir şekilde mevsimler boyunca gökyüzünde dairesel bir biçimde hareket ettiği ve yıllık takvimi de belirlediği varsayılmaktadır. Görünür hükümdar arabasının bir devrini tamamlaması, bir yıl olarak ayarlanmış ve zaman ölçüsünde kullanılmıştır (Bayat, 2017: 287, 288).

Bayat (2017) tarafından Türk düşünce sistemi açısından hakkında bilgi sahibi olduğumuz Yétiken yıldızı, bu bilgiler temelinde din dışı bir görünüme sahiptir. Bu takımyıldızının ağırlıklı olarak göçebe Türk toplumunda yllık takvimi belirlediği de görülmektedir.

\begin{abstract}
Büyükayı Takımyıldızı'nın geziși ve aldığı duruşlar, bir takvim ve hava raporu olarak işe yaramıștır. $\mathrm{Bu}$ yıldızın kuyruğunun gösterdiği yöne doğru, mevsim değişirdi. Kuyruk doğuda ise bahar, güneyde ise yaz, batıda ise sonbahar ve kuzeyde ise kışın geleceğini haber verirdi. Burcun gerilmesi ve ışıklarının azalması don olayının; daha ışıklı ve parlak olması ise kar yağışı ile sıcaklık ortalamalarının artacağına işaretti. Küçükayı Takımyıldızı, Kutup Yıldızı'na en yakın olan burçtur. Bütün burç, bu kuyruk üzerinden Kutup Yıldızı'nın etrafından döner. Türkler, bu sebeple Küçükayı burcuna önem verip Büyükayı Takımyıldızı'na da onun bekçisi olarak görmüştür. Orta Asya, Tanrı dağları ve Batı Türkistan bölgelerinde, Büyükayı Takımyıldızı’na iyi bir gözle bakılmış, Küçükayı Yıldızı’nın "Yedi Bekçisi” olarak adlandırılmıştır. Kuzey Asya ve Sibirya halkları, Büyükayı Takımyıldızı'na iyi bir gözle bakmıyordu. Bölge halklarına göre, bütün gezegenler bu burcu kovalamakta ve ondan intikam almak istemektedir. Bütün bu inanışlar, Büyükayı Takımyıldızı'nın yanında gezen, küçük yıldız (Alcor) hakkında söylenmiş efsanelerin etkisinde bu küçük yıldızın diğer gezegenlerden çalındığını anlatır. Bundan dolayı, Yedi Yıldız’ı birer hırsız ve haydut olarak görülmüştür (Gültepe, 2017: 450-453).
\end{abstract}

Gültepe'nin dile getirdiği görüşler (2017), Yétiken Takımyıldızına dair yerel inançları da göstermesi bakımından önemlidir.

Türk düşünce sistemi içerisinde Yétiken adıyla görülen bu takımyıldızı, İslamî dönem metinlerinde Yediger şeklinde görünmektedir. Ayrıca, Arapça ve Farsça gibi dillerin etkisiyle, Türk kültürü içerisinde Yétiken ylldızının Arapça Dübbüekber, Benatı-na'ş ve Farsça heft-evreng ifadeleri ile karşılandığı anlaşılmaktadır. Türk-İslam kültürü içerisinde Yétiken yıldızı, en çok Benatına'ş $\sim$ Benatü'n-na'ş kelimesi ile karşılanmaktadır. Benatı-na'ş Benatü’n-na'ş olarak bilinen bu yıldızla ilgili açıklama "Felekte iki surettir, biri Benat-ı na'ş’ül-kübradır ki Kutb-ı şimali semtinde Dübb-i Ekber suretinde merkuz yedi kutuptan ibarettir, Türkide Yediger ta'bir olunur.” (TS, 2009: 4468) şeklindedir.

\title{
Modern Türk Dillerinde Yétiken Takımyıldızının Karşılıkları
}

Türkiye Türkçesi: Büyükayı (Türkçe Sözlük, 2005: 337), Dübbüekber (2005: 583) ve Yedikardeş (2005: 2158).

Türkmen Türkçesi: Yedigen (Tekin vd., 1995: 656).

Azeri Türkçesi: Yéddigardaş (Altaylı, 1994: 1237). 
Gagauz Türkçesi: $B \ddot{u} k$ Ayı (Li, 2014: 162).

Tatar Türkçesi: Ciděgen yoldızlıgı (Çev. Öner, 2014: 72).

Başkurt Türkçesi: Yětěgen (Özşahin, 2017: 722).

Çuvaş Türkçesi: Altăr (Bayram, 2017: 34), Almăr çălmă (2017: 34) ve Pıs̆a altăr šaltăr (Skvortsov, 1982: 31).

Altay Türkçesi: Ceti kaan (Naskali ve Duranl, 1999: 60).

Kazak Türkçesi: Jetigen (Koç vd., 2003:177).

Karaçay-Balkar Türkçesi: Jetegeyle (Bayat, 2017: 287).

Hakas Türkçesi: Ceti-karakçi ve Ceti-karakşi (Bayat, 2017: 287).

Yeni Uygur Türkçesi: Yette tiken (Henzuçe-Uygurçe Luget, 1974: 28), Yette kozug (Nadžip, 1968: 603).

Yakut Türkçesi: Ulahan arayas sulus (Pekarskij, 1958: 134).

Kırgız Türkçesi: Cetigen ve Ceti arkar (Judachin, 1965: 252).

Tuva Türkçesi: Çettiganı çes sujur (Potopov ve Menges, 1934: 62).

Çalışmanın bu bölümü içerisinde başvurulan kaynaklar ve yapılan değerlendirmelerden hareketle, Yong-Sŏng Li, Yétiken yıldızının genellikle Yedi+Isim ya da $E k$ birleşmeleri ile oluştuğunu belirtmektedir (2014: 157-165). Bu takımyıldızı, Yétiken ismi dışında Modern Oğuz dillerinde yedi kardeşler, yediler gibi ifadelerle beraber, Türkmence ve Türkiye Türkçesinde Büyükayı ve Gagauz Türkçesinde Bük Ayı olarak görülmektedir (2014: 162). Zieme, modern Türk dillerinde Yétiken isminin genellikle "yıldız, Buda, kardeş, haydut, yaşlı, diken, direk ve çoban" gibi anlamlarda görüldügünü belirtmektedir (1994: 149). Bazin, Eski Türkçe dönemi yıldız isimleri ile ilişkili çalışmasında Yétiken ifadesinin genellikle yeti ve yetti gibi kelimelerden meydana gelmiş biçimlerle kullanıldığını belirtse de bu duruma aykırılık gösteren durumların Yeni Uygurcada taraza ğultus "Terazi yıldızı" ve Çuvaşçada pisak altăr țaltăr "Kuzey Kepçe Yıldız" örnekleri olduğunu belirtmektedir (1963: 579).

\section{Budist Uygurlarda Yétiken Takımyıldızı inancı}

Türk dinî sistemi içerisinde Yétiken Takımyıldızı inancını, Budist Uygurlarda görmekteyiz. 14. yüzyıla tarihlenen Yétiken Sūtra adlı metin, doğrudan Büyükayı Takımyıldızı olarak bilinen Yétiken yıldız grubuna dair inanç ve inanç ritüellerini göstermesi bakımından önem arz etmektedir. Çinceden Eski Uygur Türkçesine aktarılan bu eser, tehlike önleyici, hastalık ve doğal afetlerden koruyucu ve kötü doğumdan uzaklaştırıcı yönlere sahip bir eserdir (Wilkens, 2011: 369). Metne dair fragmanlar, ilk kez Arat (1936) tarafından TT VII'de işlense de Zieme, Arat'ın okuma hatalarını düzeltip yeni fragmanlardan hareketle, metni BT XXIII’te neşretmiştir (Elverskog, 1997: 93, Yakup, 2008: 12, 13; Zieme, 2005: 115).

Buda sözlerine dayanan Kanon koleksiyonu içerisinde yer almayan daha çok Çin Budizmi içerisindeki Taoist fikirlerin ürünü olan uydurma sūtra (apokrif) kategorisindeki bu eser, Eski Uygurca dışında Çince, Moğolca ve Tibetçe gibi versiyonlara sahiptir. Eski Uygurca metnin dayandığ Foshuo beidou qixing yanming jing 佛說北斗七星延命經 adıyla Taishō Tripitaka içerisinde 1307'de 425-426b satırları arasında yer almaktadır. "Buda Tarafından Kuzey Kepçe Takımyıldızı'nın Yedi Üyesine Tapma Yoluyla Yaşamı Uzattığı Söylenen Sūtra” anlamına gelen bu metin (Payne, 2016: 293, 294), Moğolcada tngri-yin tngri burkan nomlagsan dolugan ebügen neretü sudur nom bitig adını taşımaktadır. Ayrıca, Moğolca eser yaygın adıyla dolugan ebügen neretü odun olarak "Yedi Yaşlı 
Adam" bilinmektedir (Franke, 1990: 79, 80). Metnin Tibetçe versiyonu ise sme bdun zhes bya bas kar mäi mdo adiyla görülmektedir (Silk, 2019:227, 240).

Budist Uygur dinî yaşamı içerisinde uzun yaşam, hastalık ve acılardan kurtulma, şan ve şöhret sahibi olma gibi sloganları bünyesinde barındıran Yétiken Sutra adlı eser, sahip olduğu dinî gelenek açısından Taoizm ve Tibet Budizmi'ne dayalı Çin Budizmi'nin özelliklerini taşımaktadır (Yakup, 2008: 12, 13; Zieme, 2005: 115).

\subsection{Budist Uygurlarda Yétiken Takımyıldızı inancı geleneği: Çin Ezoterik Budizmi}

Sørensen'e göre, Tibet Budizmi, Mahāyāna geleneğine giden, içerisinde büyü ve ritüeller barındıran düşünce sistemidir. Mahāyāna mezhebinin bu kolu, dhāraṇī, mudrā ve maṇ̣ala gibi büyü tekniklerine dayanmaktadır. Tibet Budizmi, Çin başkenti olan Xian’a Tang Hanedanlığı döneminde, Subhakarasimha, Vajrabodhi ve Amaghavajra tarafından getirilmiştir. Bu dönemde Konfüçyüsçü ve Taoist öğretilere de ustalık yapan bu isimler, Çin'de hanmi adı verilen Tantracı sistemi kurmuşlardır (2011b: 157, 158).

Capitanio, Tang Hanedanlığı döneminde Tibet Budizmi'ne dair pek çok uygulamanın Taoist ritüeller ile işlendiğini belirtmektedir. Kötülüğe karşı koruyuculuk, yağmur yağdırma, cinlerden ve hastalıktan korunma ve kurtulma gibi birçok Taoist uygulama, Çin Budizmi içerisinde işlenmiştir (2011: 530, 531). Copp’a göre, Tang Hanedanlığı döneminde özellikle resimlerle süslenen metinler, Tantrik Budizm’in Çin'deki popülerliğini ortaya koymaktadır. Budist heykelcilikten büyü sözlerine kadar etkisini her alanda gösteren Tibet Budizmi, yeni ritüel teknikleri ile beraber abhiseka ve dhāraṇ̄ uygulamaları ile Çin'de yoğun bir şekilde hissedilmiştir (2011: 431).

Çin Ezoterik Budizmi içerisinde Büyükayı Takımyıldızı, Beidou adlandırmasına sahiptir. Yengel'e göre, takımyldızlara Çin astrolojisinde insanların davranışlarını belirleyen mitolojik yakıştırmalar verilmese de Çin astrolojisinde özellikle Taoist etkilerden dolayı, mitolojik ve tanrısal anlamlar yüklenmektedir (2018: 49). Yengel tarafından dile getirilen görüşü sağlamlaştıracak düşünce Mollier (2008) tarafından dile getirilmiştir. Mollier'e göre, Beidou, yerel Taoist fikirlerden Budizm'e adapte edilmiştir. Yedi Ylldız, Yedi Tathāgata Buda ile eşleştirilmiştir. Bu Yedi Tathāgata Hekim Buda olan Bhaiśajyaguru'nun tanrısal niteliklerini içermektedir (2008: 141). Yengel (2018) devamında Çin düşünce sistemi içerisinde takımyıldızların sahip olduğu öneme de değinerek Çin inanç sisteminde bu takımyıldızına dayanak olan görüşlere yer vermiştir. Çin inancına göre, bireyin yaşadığı hastalıklar geçmişteki kötü karmalardan kaynaklanmaktadır. Olumsuz karma, bu düşünce sisteminde gezegenler tarafından zarara uğramış bir doğuma işarettir ve bu işaret kişiye yaşamı boyunca hastalık ve felaket getirmektedir. Bu yönüyle, kişinin zarara uğramama adına sığındığı tek yer, gök ve gökteki yıldız ya da gezegenler olmuştur (2018: 49). Bu doğrultuda Pregadio, Beidou'nun göğü ve yeri yöneten evrenin karmaşık birliğini sembolize eden bir terim olduğunu belirtmektedir. Beidou, Taoist düşünce içerisinde hem Ying hem de Yang kavramı ile ilişkili olarak Kuzey yönünü sembolize etmektedir. Bu takımyıldızı, ölüm ve yaşam, ödül ve cezalandırma gibi ikili doğaya sahiptir. Taoizm'de bu yıldız, meditasyon ya da ritüelleri yönlendirmesi, kötü ruhları kovma, birinin kaderinde yazılı olanı silme ve gök yolunu hem meditasyon hem de ritüeller ile açma fonksiyonuna (2008: 224) sahiptir.

\subsection{Eski Uygurca Yétiken Sūtra'da Büyükayı Takımyıldızı'na dair uygulamalar}


Çalışmanın bu bölümü, Eski Uygurca Yétiken Sūtra yoluyla Büyükayı Takımyıldızı’na dayalı inanç uygulamalarını içermektedir. BT XXIII içerisinde Zieme (2005) tarafından işlenen metinde tespit edilen dinî uygulamalar, Türk Budizmi özelinde görülen dinî etkilerin dayandığı geleneği göstermesi bakımından önemlidir.

\subsubsection{Takımyıldızlara ilahlık yükleme}

Eski Uygurca Yétiken Sūtra özelinde tespit ettiğimiz ve metnin Çince versiyonuna da dayanan Taoist özelliklerden biri de, Eski Çin dini içerisinde insan kaderini tayin edici ve denetleyici rolde olan Büyükayı Takımyıldızı'nı oluşturan Yedi Yıldız'a her biri ayrı ilahlık yükleme durumu gelmektedir.

Uygurca metinde, Yedi Yıldız’a dair adlandırmalar Tamlang <Çince T’an-lang 貪狼, Kumunsi <Çince Chü-men巨門, Luusun <Çince Lu-ts'un 祿存, Vunkiu <Çince Wen-ch'ün 文曲, Limçin <Çince Lien chen 廉貞, Vukuu <Çince Wu-ch'ü 武曲 ve Pukunsi <Çince P'o-chün 破軍 şeklindedir (Eberhard, 1936: 99).

Robson'a göre, Çin'de her bir yıldızın sahip olduğu sembolik bir değer vardır. Örneğin, Pukunsi yıldızı boşa harcamayı kontrol etme, Vukuu yıldızı resmî ilişkileri kontrol etme, Limçin yıldızı, tartışmaları ve kavgaları kontrol etme, Vunkiu yıldızı kötü rüyaları kontrol etme, Luusun yıldızı, 1000 şeytani varlığı kontrol etme, Kumunsi yıldızı haksızlığa uğramayı engelleme ve Tamlang yıldızı ruhları kontrol etme işlevine sahiptir (2008: 161). Bu yönüyle, Çin ve Uygur kültürlerinde Yétiken Takımyıldızının yedi üyesinin her birinin birbirinden bağımsız ancak olumlu bir sonuca ulaştıracak yönü söz konusudur.

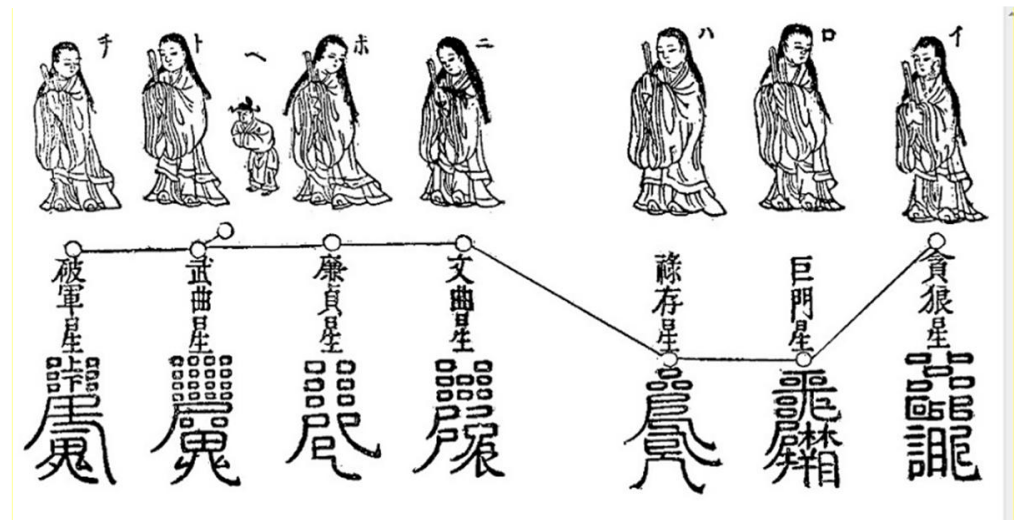

Resim 3: Taishō Tripitaka İçerisinde Yer Alan Yedi Yıldız İlahı (https://21dzk.l.utokyo.ac.jp/SAT/satdb2015.php?lang=en Erişim Tarihi: 14.07.2020).

Her bir ilah, Resim 3’te görüldüğü üzere, dişi cinsiyette uzun saçlı, elde asa gibi benzeri bir donanımla Kuzey Kepçe Yıldızı'nın gökyüzündeki sıralamasını göstermektedir. Bu sıralama Uygurca metin içerisinde de görülmektedir. Uygurca metne göre, ilk yıldız [ta]mlaך olup p[ukuns]i yıldızına kadar tüm yıldızlar ve bu yıldızların muskaları ve onlara sunulacak tahıllar yoluyla refaha ve mutluluğa erişileceği anlatılmaktadır.

BT XXIII G oo9-o18: eyilki [ta]mlay atl(2)g yultuz ol: vuusı bo erür: küskü yıllhg kişi bo yultuzka sanlıg tugar: livi aşı üyür tögisi té[ti]r: ada tuda boldukta [bo] nom [bi]tigke [t]apımıp udunup [vuusin] et'özinte tutmış [k(e)rgek] ulug ögrünç sevinç bolur "ilk ylldız Tamlang <Çince T'an-lang 貪 狼 yıldızıdır. Muskası şudur: Sıçan yılında doğan biri bu yıldızın altında doğar. Onun yemek sunusu, 
"kabuğu soyulmuş darı"dır. Tehlike durumunda bu öğreti kitabına ibadet edip muskasını bedende taşımak gereklidir. Böylece, refah ve huzur gerçekleşir.” (Zieme, 2005: 130, 131).

BT XXIII G o73-o82: yétinç p[ukuns]i atl(2)g yultuz ol vuusı bo erür: yunt yıllhg kişi bo yultuzka [livi] aşı yaşıl burçak [tetir : ada tuda bolḍukta] [bo nom bitigke tapını]] [udunup vuusın et 'özinte] [tutmış k(e)rgek : adası erter] [ulug ögrünçlüg sevinçlig] "Yedinci yıldız, Pukunsi < Çince P'o-chün 破 軍adlı yıldızdır. Muskası budur. At yılında doğan kişi, bu yıldızın altında doğar. Onun yemek sunusu, "sarı fasulye"dir. Tehlike durumunda bu öğreti kitabına tapınıp muskasını bedende taşımak gereklidir. Böylece, refah ve huzur gerçekleşir.” (Zieme, 2005: 134, 135).

Uygurca versiyonda 1'den 7'ye kadar olan yldız sıralaması içerisinde, kalıp ifadeler söz konusudur. Yedi Yıldız'a dair bilgiler, bu takımyıldızının gökyüzündeki sıralamasından hareketle oluşturulmuştur. Her bir yıldızın adı verilip devamında 12 hayvanlı takvimdeki yıl karşılı̆̆ı ve bu yıldızlara ait yemek sunuları gösterilmiştir. Bu yıldızların Budist inanırlarca kullanılma durumu, tehlike ve hastalık durumudur. Bedende taşınarak tehlike ve kötülüklerden uzak kalınacağı fikri, Yedi Yıldız’la ilgili tanıtım bölümünün tümünde görülen bir özelliktir.

\subsubsection{Muskalar}

Franke'ye göre, Eski Uygurca Yétiken Sütra'nın dayandığı Çince Kuzey Kepçe Yıldızı metni Taoist bir kaynaktan anonim bir şekilde Budist role çekilerek yaşanılan dönem içerisinde popüler hâldeki Ezoterik büyü uygulamaları ile insanların dikkatini çekmiştir (1990: 106). Bu popüler inanç, Çin düşünce sistemi içerisinde Taoizm ile sembolleşen yerel inançların etkisini de göstermektedir.

Robson'a göre, Çin geleneğinde Kuzey Kepçe Yıldızı Sūtrası olarak bilinen bu metinde yer alan muskalar, insan vücudundaki makro ve mikro kozmiği yansıtan özel yıldızlara atıfta bulunmaktadır. Her yıldızın altında bir muska bulunmaktadır. Bu metinde yer alan muskalar, uygulayıcılarına tehlike ve felaketlerden korunma firsatı vermektedir. Bu muskalarla kişi, şeytanların kendine musallat olmasından, işinde ilerleme, sağlık ve zenginliğe ulaşma, kolayca doğum yapma gibi faydalara erişmektedir (2008: 150, 151).

Sørensen'e göre, Çin Budistleri, muska ve tılsımlar içeren uygulamaları, Taoizm’den almıştır. Güzelce işlenmiş bu muskalar, koruyucu olduğu düşünülen göksel vücut ya da takımyldızlarımı gösteren astrolojik sembollerden oluşmuştur. Çin Budizmi içerisindeki Taoist muska geleneği, ylldız kümelerinin negatif etkilere karşı doğaüstü güçlerden ileri gelen koruyuculuk inancını yansıtır. Bu doğrultuda, muskalar yıldız şekilleri ile kozmik tehlikeleri yok ederek huzurlu bir dünya vaadiyle inanırlarına seslenmiştir (2011a: 232, 233).

Çin Taoizmi'nin etkisini taşıyan ve Ezoterik Budizm içerisinde de görülen bu muskalar, Uygurca versiyona ait fragmanlarda da yer almaktadır. Uygurca versiyon içerisinde yer alan bu muskaları, Uygurca versiyona dayalı olan Moğolca metinde de görmekteyiz. 


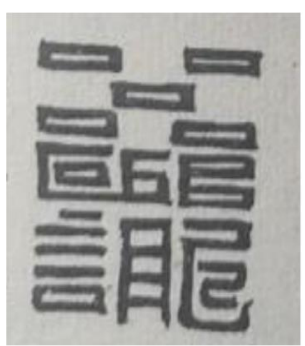

Resim 4: Muska I

(Ligeti, 1967: 103)

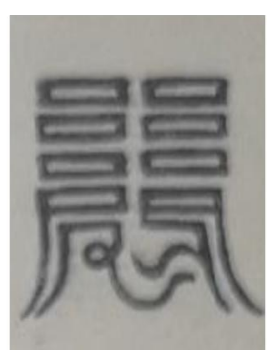

Resim 8: Muska V

(Ligeti, 1967: 105)

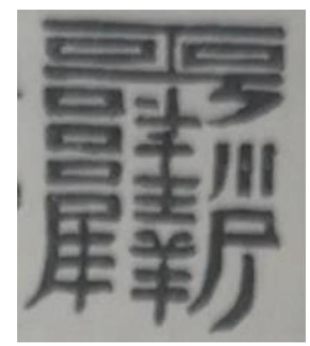

Resim 5: Muska II

(Ligeti, 1967: 104)

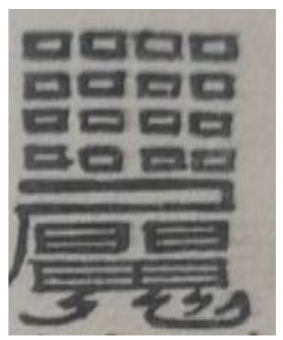

Resim 9: Muska VI

(Ligeti, 1967: 105)

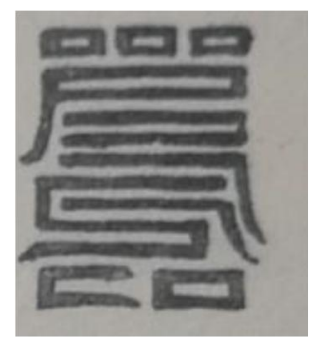

Resim 6: Muska III

(Ligeti, 1967: 104)

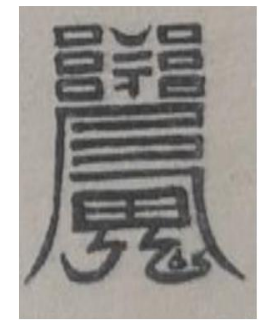

Resim 10: Muska VII

(Ligeti, 1967: 105)

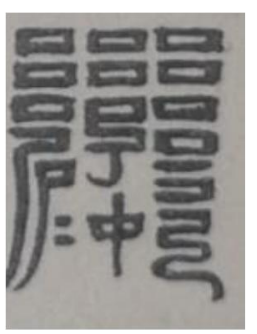

Resim 7: Muska IV

(Ligeti, 1967: 104)

Bu muskaların her biri, Yedi Yıldız ile ilişkili koruyucu güç olarak görülen nesnelerdir. Tantrik Budizm ile etkisini gösteren büyü metinlerinin vazgeçilmez ögesi olan muskalar, Sørensen'in de belirttiği üzere (2011a: 232, 233), köken olarak Çin toplumu içerisinde beliren Taoist etkilere gitmektedir. Bu muskalar, Uygurca versiyon içerisinde Yedi Yıldız’a dair bilgilerin verildiği giriş bölümünde şu şekilde görülmektedir.

BT XXII g o26-o31: ada tuda boldukta bo nom bitigke tapınıp udunup vuusın et'özinte tutmış k(e)rgek: adası erter : ulug ögrünçlüg sevinçlig bolur "Tehlike ve sıkıntı durumunda bu öğreti kitabına ibadet edip bu yıldızın muskasını kendi vücudunda taşımak gereklidir. Böylece, mutlu ve sevinçli bir duruma ulaşlır.” (Zieme, 2005: 132).

Yétiken metni içerisinde yer alan muskalar, Uygurca vuu < Çince fú 符 ifadesi ile adlandırılmaktadır. Robson'a göre, Taoist gelenekte, altın, giysi, kâğıt üzerine süslenerek yazılan muskalar, genellikle vücuda takılmakta, elbiseye asılmakta ve manastırlara gömülmektedir. Muskalar, arzu edilen şeyin gerçekleşmesini sağlayan tehlikeli ya da hastalık verici durumları, kötü ruhları engelleyici gücü olan nesnelerdir. Ezoterik Çince muskalar, esrarengiz yazılara sahiptir. Bazı muskalar, bu yönüyle boyut bakımından insan gözü ile görülebilecek tarzda olabileceği gibi gözle görülemeyecek şekilde de oluşturulmaktadır (2011: 225, 226). Bu yönüyle, Uygurca ve Moğolca versiyon içerisinde gördüğümüz muskaların sahip olduğu nitelik, ifade ettiği değer net değildir. Bu da bu muskaların esrarengiz olduğu fikrini doğrulamaktadır.

\subsubsection{Yemek sunuları}

Chiang'a göre, Taoizm'de ritüeller, genellikle Tao dini içerisinde efsanevi bir kişilik olan Chen Fuhui ve öğrencilerinin gerçekleştirdiği uygulamalara dayanmaktadır. Bu uygulamalar, yerel tanrılara tapma, bu yerel tanrıların doğum günlerini kutlama gibi faaliyetler içermektedir. Yerel tanrılara tapma ve onlara adaklar sunma faaliyetleri Taoizm'de jiao olarak adlandırılmaktadır (2016: 58). Bu terim, Çin 
toplumu içerisinde barış ve güvenlik, salgınlardan korunma, kutsanma, ateşten korunma gibi amaçlar için kullanılmaktadır. Taoist bir rahip, aile üyelerinin adını taşıyan sunularla barış ve zenginlik getirecek tanrıları çağırarak bir yenilenme ritüelini başlatmaktadır. Tapınak ritüellerinde ise Taoistler, hem bireysel hem de toplumsal değer adına çeşitli ilahlar, muskalar, büyülü sözler ve metinler kullanmaktadır (https://www.bbc.co.uk/religion/religions/taoism/rites/rites.shtml Erişim Tarihi: 14.07.2020).

Teiser'e göre, Çin'de Taoizm ve Budizm'in iç içe geçmesi, ritüellere de yansımıştır. Çin ritüellerinde, özel bir ilah ya da özel bir varlı̆̆a sunular verme, hastalıklardan kurtulma olarak yorumlanmıştır. Aynı zamanda, bu ilahların kişiye zorluk yaşatan şeytanlarla mücadelenin bu özel varlıklara yemek, tahıl, çiçek, tütsü gibi sunular vererek gerçekleşmesi inancı söz konusudur (1996: 21-22).

Wei ve çalışma arkadaşlarına göre, Çin Taoist geleneğinde tarım ürünleri de sunu olarak ilahlara adanmıştır. Yerel halk, atalardan kalma ritüeller ile çeşitli sebzeleri de sunu olarak kullanmıştır. Yerel halk, ritüeller esnasında tahıllara sıklıkla başvurup bunu bir ibadet durumuna getirmiştir (http://www.okinoshima-heritage.jp/files/ReportDetail_79_file.pdf Erişim Tarihi: 14.07.2020).

Uygurca versiyon içerisinde Çin günlük yaşamında sıklıkla tüketilen tahıllara dayalı ritüeller de görülmektedir. Bu ritüel, tahıl kategorisi içerisinde yer alan darı, fasulye, pirinç gibi besinlerle gerçekleşmektedir. Tantrik Budizm'e dair bir uygulama olmaktan çok Taoist bir ritüel olarak Çin yerli inancını yansıtan Yedi Yıldız ilahlara sunulan tahıl ürünleri şunlardır:

\begin{tabular}{|l|l|l|l|}
\hline Yıldız Adı & Yemek Sunusu & Tahıl & Türkçe Çeviri \\
\hline Tamlan & livi aşı & üyür tögisi & Kabuğu soyulmuş darı \\
\hline Kumunsi & livi aşı & konak tögisi & Kabuklu darı \\
\hline Luusun & livi aşı & tuturkan & Pirinç \\
\hline Vunkiu & livi aşı & buğday & Buğday \\
\hline Limçin & livi aşı & kentir urugı & Kenevir tohumu \\
\hline Vukuu & livi aşı & kara burçak & Siyah fasulye \\
\hline Pukunsi & livi aşı & yaşıl burçak & Sarı fasulye \\
\hline
\end{tabular}

Tablo 1: BT XXIII'te Yer Alan Yemek Sunusu (Zieme, 2005: 130, 132, 134).

Uygurca versiyon içerisinde, giriş bölümünde her bir yıldızın sahip olduğu muska ve bu varlıklara dua etmede kullanılacak yemek sunusu içerisinde sıraladığımız bu tahılların Çin toplumuna özgü ritüellere

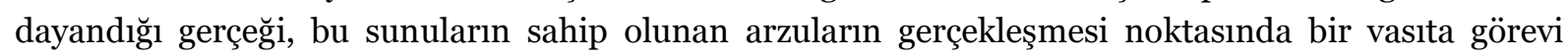
gördüğünü göstermektedir.

\subsubsection{Takımyıldızlara yakarma}

Eski Uygurca metnin sahip olduğu Taoist etkilerden biri de, gökte insan kaderini denetleyen, tayin eden ylldız ve gezegenlere olan inançtır. Çin toplumu içerisinde öneme sahip Beidou kültürü, Uygurlarda da etkisini göstermektedir. Uygurca versiyonda Yedi Yıldız'n her birine yükünür biz "saygıyla ibadet ediyoruz" ifadesiyle yakarış söz konusudur. Her bir yıldız, bir Buda kişiliğinde adlandırma ve sembollere sahiptir. BT XXIII özelinde Yedi Yıldız Tanrı için kullanılan sembolik anlatımlara bakıldığında, Tamlay yıldızı için "Siz, Doğu dünyasında Manevi Güç Yoluyla bilinen "Kutlu Zaferi” elde etmiş Budasınız." (Zieme, 2005: 135); Kumunsi yıldızı için "Siz, Harika Mücevher 
Dünyasının Olduğu Doğu Ülkesinde “Aydınlanma Işığının Sesi” adlı Buda’nın somutlaşmış şeklisiniz.” (2005: 135), Luusun yıldızı için Siz, Doğu Ülkesinde "Mükemmel Altın Işık” Yoluyla Bilinen Buda'nın somutlaşmış şeklisiniz" (2005: 137), Vunkiu yıldızı için "Siz, "Pişmanlığın Olmadığı" Doğu Ülkesinde, "En Yüksek Erdemlerle” Bilinen Buda'nın somutlaşmış şeklisiniz.” (2005: 137), Limçin yıldızı için "Siz, Tamamen Doğu Ülkesine Yerleşmiş "Bilgelik, Ruh ve Akla Sahip” Buda'nın somutlaşmış şeklisiniz." (2005: 137), Vukuu yıldızı için "Siz, "Dharma’ya Adanma"nın olduğu Doğu Ülkesinde, Dharma Okyanusu'nun Sevincine Sahip Buda'nın somutlaşmış şeklisiniz.” (2005: 137) ve Pukunsi yıldızı için "Siz, Vaiḍūrya kalıntılarını üzerinde taşıyan Doğu Ülkesinde, Vaiḍūrya adlı Buda'nın somutlaşmış şeklisiniz." (2005: 137) ifadelerinin olduğu görülmektedir. Bu ifadeler, birer sembolik değer olarak Taoist gelenek içerisinde yer alan Beidou kültünü oluşturan yerel tanrıların Budistleştirildiğini göstermektedir.

Eski Uygurca Yétiken Sutra içerisinde tespit edilen Taoist etkiler dışında, Tibet Budizmi’ne dayalı dinî gelenek, metinde Buda ve Bodisattva kişilikleri ve mantralar ile görülmektedir.

\section{2. 5. Buda ve Bodisattva kişilikleri}

Eski Uygurca Yétiken Sutra özelinde görülen Tantrik özelliklerden biri, Çin Ezoterik Budizmi içerisinde öneme sahip Buda ve Bodisattva varlıklarıdır. Bunlar arasında, Avalokitesvvara (Guanyin 觀 音, Guanshiyin 觀世音), Mañjus rī (Wenshushili 文殊師利), Samantabhadra (Puxian 普賢), Amitābha (Amituo 阿彌陀), ya da Amitāyus (Wuliangshou 無量壽), Bhaisajyaguru (Yaoshi. 藥師), ya da Bhaisajyarāja (Yaowang 藥王) gelmektedir (McBride II, 2011: 215-219). Bu kutsal Buda ve Bodisattva kişilikleri, metinde de görüleceği üzere, Buda'nın vaaz verdiği, verilen vaazın samimi bir kalple uygulanışı ile yaşanacak etkileri ve elde edilecek faydaları göstermesi bakımından önemlidir.

\subsubsection{Buda Amitābha ve Saf Ülke "Sukhāvatī”}

"Sonsuz Işık" anlamına gelen Amitābha, Budizm'de kendi Buda ülkesine sahip göksel ya da mitik Buda olarak adlandırılır. Amida Buda olarak bilinen bu varlık, Çincede 弥陀 “Mī tuó”, Japoncada Amidabutsu ya da Muryōkō-butsu ve Korecede Amit'a pul olarak görülmektedir (Buswell ve Lopez, 2014: $34)$.

Keown'a göre, Beş Tathāgata'dan biri olarak görülen Amitābha, "Farkındalığın Ayrımına Varma"sı ile bilinmektedir. Sukhāvati Sūtra’ya göre, Amitābha önceki yaşamında Dharmakara adlı bir rahipti. Kendisi bir Bodisattva olarak Buda yolunda ilerlerken saf ve süslü bir dünya inşa etmiştir. Dharmakara, Budalığa ulaşır ulaşmaz, Amitābha Buda olarak bu saf dünyada yani Sukhāvatīde yaşamaya başlamıştır. Bu dünyada onun etrafı, sayısız Bodisattvalar ile çevirili olup yeniden doğum olayında doğumun gerçekleşeceği bir mekân ile çağrışıma sahip olmuştur (2003: 10).

Sanskritçe kökenli Sukhāvatī ifadesi ise Çincede 極楽 “Jīlè”, Japoncada Gokuraku, Tibetçede bde ba can (Buswell ve Lopez, 2014: 866) "Saf Ülke" olarak gösterilmektedir. Bu terim, Mahāyāna mezhebi içerisinde doğrudan Amitābha Buda'ya yönelik bir ifadedir. Bu terim, Çincede jingtu ve Japoncada jōdo olarak da görülmektedir (Buswell, 2004: 698). "Kutsal Ülke" ve Batı Cenneti” olarak da adlandırılan bu yer, Mahāyana sūtralarda Amitābha tarafından yönetilen śraddhā denilen inancı yansitan ve yeniden doğuşun olduğu bir yer olarak gösterilir. Mutlulukla burada yaşayan kişi, kolaylıkla nirvāṇa'ya ulaşmaktadır (Keown, 2003: 282). 
Eski Uygurca metin içerisinde geçen tamutakı emgektin ozup kutrulup ertiyü meyilig yertinçüte abita burhan uluşınta tugar (Zieme, 2005: 140) "Cehennemdeki acılardan kurtulup mutluluğun had safhaya ulaştığı Amitābha ülkesinde yani Sukhāvatī'de doğar.” ifadesi, bu yönüyle Tantrik Budizm içerisinde temel bir figür olan Amitābha ve Sukhāvatī kültünün etkisini göstermektedir.

\subsubsection{Mañjușrī}

Tam ismi Manjusrikumara-bhuta olan Bodisattva Mañjușrī, Mahāyāna Budizmi’nde göksel ya da mitik değere sahip bir Tanrıçadır. Kendisinden erken dönem Mahāyāna metinlerinden Prajñaparamita Sūtra'da bahsedilir. Kendisi, prajña olarak bilinen içsel bilgi ile gösterilmiştir. Sonradan Mañjuśrī, Tantrik Budizm'de Manjusnmula-kalpa ile ilişkili görülmüştür (Keown 2003: 172). Çin'de Mañjuśrī inancı, 4. yüzyılda ortaya çıkıp Monju şeklinde Japonya'ya geçmiştir. Çin'de Mañjușrī, Jamdpal olarak bilinen Tibet Budizmi’nde önemli bir figür olmuştur (Irons, 2008: 330).

Uygurca versiyon içerisinde yer alan ol üdün t(e)pri t(e)yrisi burhan mançuşiri bodis(a)t(a)vka inçe tep y(a)rlıkadı (Zieme, 2005: 138) "O vakit, Tanrılar tanrısı Buda, Mañjušrīye şöyle buyurdu." ifadesi, metnin taşıdığı Budist değeri, Bodisattva Mañjuşrī katında söyleme döndüren bir ifade olarak görülmektedir.

\subsubsection{Mantralar (Büyülü sözler)}

Wallace'a göre, Tantrik Budizm'e dayalı metinlerde mantra ve dhāraṇī denilen duaların okunması, uzun yaşam, hastalıktan ve şeytanların kötü etkilerinden kurtulma, refaha ve huzura ulaşma, öldükten sonra mutlu bir şekilde doğma gibi amaçlardan ileri gelmektedir (2015: 883).

Apokrif yani uydurma sūtra kategorisindeki bu eserde yer alan büyü sözleri, Keyworth’a göre uydurulmuş büyü ifadeleridir. Keyworth'a göre, uydurulmuş bu metinler, dhāraṇīlerden arta kalan yazılardan ortaya çıkmış, anlaşılmaz sözler olarak karşımıza çıkmaktadır. Bu metinlerin çoğu, om ifadesi ile başlayıp svāha $\bar{a}$ ifadesi ile sona ermektedir. Uydurma sūtralarda bu ifadeler, metne geçerlik ve Budist özellik katmaktadır. Bu metinler, Brahmi ya da Sanskritçe telaffuza yakın bir şekilde uydurulmuş dhâraṇī ya büyülü sözler olarak koruyuculuğa sahiptir (2016: 10). Metnin Çince versiyonu başta olmak üzere, diğer versiyonlarında ve özellikle Uygurca versiyonda da uydurulmuş Sanskritçe söz ve dhāraṇileri görmekteyiz. Uygurca versiyonda bu tür ifadeleri, namo samanta budanan oom çin vunni svaha ve namo samanta budanan oom nimarini agadana para maru tusu svaha gibi örnekler de buluruz. Apokrif metinler içerisinde yer alan büyülü sözlerin metni Budist seviyeye çekmesi, Çin düşünce sisteminde uydurulmuş Sanskritçe sözler sayesinde gerçekleşmektedir. Bu durum, Çin Budizmi içerisindeki Taoist etkilerden kaynaklıdır. Pregadio'ya göre, Taoizm'de büyü, fiziksel ve mental teknikler ile süper üstü güçler edinme olarak bilinmektedir. Ruhlar ve ilahlar gibi doğaüstü güçleri kontrol amaçlı bu kavram, kişinin varlığını sürdürmeyi gösterir (2008: 116). Bu doğrultuda, metindeki uydurma büyülü sözlere rağmen 14. yüzyıla tarihlenen Taoist ve Tantrik fikirlerin birleşimi olan Yétiken Sūtra içerisinde, Yedi Yıldız'a dair büyülü sözleri okuma yoluyla çeşitli faydalar elde edilmektedir.

\subsubsection{Faydalar}

Hidas'a göre, Tibet Budizmi içerisinde çok sayıda büyülü sözün vaadi, kötü eylemlerden ve günahlardan arınma, aynı zamanda, olumlu bir konuşma ile doğurganlık vaat etme, eski yaşamların hatırlanması, refah, saygı, mutluluk, güzellik, korkusuzluk, uzun ömürlülük, tam bilinç, yeniden doğuş, 
korunma, doğaüstü güçlerin kazanılması gibi faydalar üzerinedir (2015: 131). Bu yönüyle, Tibet Budizmi'nde belirginleşen bu amaçlar silsilesi, Çin Budizmi içerisinde de görülmektedir. Hem Taoizm hem de Ezoterik Çin Budizmi’nin popüler uygulamaları, yaşam süresini uzatmaya dayalı ritüellere sahiptir. Bu ritüel metinlerinden biri de, Çinceden Eski Uygurcaya çevrilen Yétiken Sūtra'dır. Metnin Taoist geleneğe ait olduğu eserin Çince başlı̆̆ içerisinde yer alan yán ming 延命 "ömrünü uzatma" ifadesi ile görülmektedir. Bu da ele alınan metnin ait olduğu geleneği gösteren anahtar kavramlardan biridir. Tantrik Budizm'in etkisindeki Çin Budizmi ile Taoizm, tarihsel süreç içerisinde Çin toplumunda aynı dönemde gelişme yaşamıştır. Her iki öğreti grubunda da uzun yaşama, şans ve talihe, refah ve mutluluğa, şeytanların gazabından kurtulma gibi amaçlar söz konusudur.

\subsubsection{Acılardan kurtulma ve yeniden doğum}

BT XXIII G 172-184: birök kim kayu tözünler ogh : tözünler kızı ertmişler : tamuta tugup adruk adruk açıg tarka emgek emgendeçiler üçün : bo nom bitigig eşidip kertgünç köyülin ayasar agırlasar tapınsar udunsar : ötrü ol üzütler tamutakı emgektin ozup kutrulup ertinü meĐillig yertinçüte abita burhan uluşınta tugar "Soylu erkek ya da kadınların bu dünyadan göçmüş, cehennemde doğup farklı farklı acılar çeken akrabaları, bu öğreti kitabını duyup bu kitaba samimi bir gönülle ibadet ettiklerinde, cehennemde acılar içerisindeki ruhları azaptan kurtulup sonsuz Mutluluk Ülkesi olan Sukhāvatī'de doğacaktı." (Zieme, 2005: 138, 139).

$\mathrm{Bu}$ metin özelinde görülen faydalardan biri de, kişinin bu dünya ile ilişiği kesilmiş ölü ruh konumundaki akrabalarının yaşadıkları acıların ortadan kalkmasıdır. Uygurca metin bu öğretiyi duyan kişinin saf bir imanla bu öğretiye ibadet ederek hem kendini hem de ölen akrabalarını kurtarıp Sukhāvatī de doğacağını söylemektedir.

\subsubsection{2. Şeytan ve hayaletlerin sebep olduğu korkudan kurtulma}

BT XXIII G 185-195: tözünler ogh tözünler kızı azu yekke içgekke basındurmış bolsar : ters tetrü şmnu örletmiş erser : yavız tül tüşeser : ermäz irü b(e)lgü közünser : ögi köyüli ürkser belinleser : birök bo nomug eşidip boşgunsar tutsar :[...] "Soylu erkek ya kadın her kim, şeytan ve hayaletler tarafından rahatsız edilse, korkutulsa, kötü düş görse, aklı ve gönlü korksa, bu öğreti kitabını duyup []” （Zieme, 2005: 140,141).

Uygurca versiyon içerisinde ilgili bölüm, hayaletlerin, zombi görünümlü varlıkların kişiye musallat olmasını anlatır. Bu bölüm, metnin devamı noktasında eksikliklere sahiptir. İlgili bölüm, T1307_.21.0426a27'de yer alan jỉ dé hún pò àn ning 即得魂魄安寧 ve yǒng wú 永無 kǒng bù 恐怖 ifadeleriyle tamamlanmaktadır. Bu bölüm, bu öğreti kitabının duyulması durumunda kişinin aklına ve gönlüne hücum eden kötü ruhlu varlıkların ortadan kalkacağını ve tüm korkuların yok olacağını söylemektedir.

\subsubsection{3. İyi bir şöhrete ve makama sahip olma}

BT XXIII G 196-208: [kim kayu tözünler oglı tözün]ler kızı antag y(e)me ugurı yıkı bolup begke eşike ınanç tayanç bolgah küseser : et özzin emgenip yanturu yana işke yumuşka bardaçı bolsar [inçip ] [ ...] [ beg-ke] eşike (?) [inanç tayanç] bolup at [küsi asılu]r : üstelür [ulug ö]grünçlüg sevinçlig bolur "Soylu erkek ya da kadından biri, bir hükümdar ya da kraliçeye danışman olmak istese, bedenini acılardan kurtarıp onun hizmetine girmek istese, bu öğreti kitabına ibadet edip dilediği şekilde prens ya da kraliçeye yakın olup ünü artar ve mutlu bir şekilde şöhretle yaşar.” (Zieme, 2005: 140,141). 
Uygurca versiyon içerisinde yer alan eksiklikler, aynı şekilde T1307_.21.0426bo2-03-04 yoluyla tamamlanmaktadır. Burada, prens ya da prenseslerin hizmetinde çalışarak mesleki olarak ilerleme, şan ve şöhrete ulaşma durumu söz konusudur.

\subsubsection{Hastalıktan kurtulma}

BT XXIII G 209-219: kayu tözünler ogh tözünler kızı a[nçulayu] y(e)me agır ig agrı üze [e]girtip ol ig[-intin] agrıginton [öyed]geli küseser: inçip [ar]lg evde tütsük [köyürüp] bo nom [bitig]ke [tapınıp u]d[unup] [ ...] bo nomu[g] [okıp] barça öyedgey "Soylu erkek ya da adın, ağır bir hastalığa yakalanıp bu hastalık ağrılarından kurtulmak istese, temiz bir odada tütsü yakıp bu öğreti kitabını okuyup buna ibadet ederek tüm hastalık acılarından kurtulacaktır." (Zieme, 2005: 140-142).

Uygurca versiyon içerisinde yer alan bu bölüm, hem Taoizm hem de Tantrik Budizm özelinde hedeflenen hastalıklardan kurtulma arzusuna uygunluk göstermektedir. Her iki öğreti içerisinde de temel hedef popüler bir şekilde hastalık acılarından kaynaklı sıkıntıdan kurtulma, bedeni ve ruhu bu acılardan uzak tutmadır.

\subsubsection{Zenginliğe ulaşıp evlatlarına miras bırakma}

BT XXIII G 220-230: [birök] kim kayu tözün[ler oglı] tözünler kızı [yo]l yorıahı rak bargah satıg yulug kılgah sakınsar : tilemiş ed t(a)var üze küsüşin [... ] "Soylu erkek ya da kadın uzak bir yola mal mülk kazanmak için giderse ...” (Zieme, 2005: 142).

Uygurca versiyon içerisinde ilgili bölüm, ticaret temelli elde edilecek zenginliğe işaret etmektedir. Uygurca bölüm, eksiklikler barındırmaktadır. Uygurca bölümün sahip olduğu eksiklikler, metnin Çince versiyonu ile tamamlanabilmektedir. İlgili bölüm, T1307_.21.0426bo4'te ruò yù cǐ jīng xīn jīng gòng yăng 若遇此經信敬供養 ve ji dé qiú cái chḍng sui chū rù dà ji 即得求財稱遂出入大 yoluyla tamamlanmaktadır. Bu ifadeler, "O zaman bu öğreti kitabına saf bir gönülle ibadet edip tüm arzularına ulaşıp kendisi de evlatları da refah içerisinde yaşayacaktır." anlamına gelmektedir. Hem Taoizm hem de Tantrik Budizm temelinde popüler yöne sahip bu sözler, hastalık acıları ve şeytanlar kaynaklı sıkıntılardan uzak kalma amaçlı dünyevi arzuları oluşturmaktadır.

\subsubsection{Doğacak çocuğun kötü etkilerden uzak uzun bir yaşama sahip olma}

BT XXIII G 243-253: [birök kim kayu kunçuylar] ... özi uzun bolur "Herhangi bir prens ya kadın, ...yaşamı uzun olacak." (Zieme, 2005: 142).

Uygurca versiyon içerisinde ilgili bölüm, tamamen eksiktir. Metnin sadece baş cümlesi ve son cümlesinin göründüğü bu bölüm, bir kadının kötü etkiye sahip bir gezegen ayı içerisinde çocuğunu doğurmaması için yapılması gereken uygulamaları gösterip bu doğrultuda doğacak çocuğun şans ve talihe sahip olup uzun bir yaşam süreceğini ifade etmektedir. Eksik kalan bu bölüm, Uygurca versiyonun dayandığı Çince metin ile tamamlanmaktadır. Çince versiyonda T1307_.21.0426bo8 içerisinde yer alan ruò yù cǐ jīng xỉn jīng gòng yăng 若遇此經信敬供養, jī yĩ dé mǔ zĭfụn jiě è nàn xiāo chú 即一得母子分解厄難消除; T1307_.21.0426bo9 suǒ shḍng ér nǚ 所生兒女, jị̣ dé duān zhèng cháng ming guó bào 皆得端正長命果報 ifadeleri “O zaman saf bir gönülle bu öğreti kitabına ibadet edip kötü ruhlardan kurtulacaksın. Doğacak oğlun ya da kızın şanslı ve talihli olup uzun bir ömre sahip olacaktır." anlamlarına gelmektedir. Bu yönüyle, Uygurca versiyonda eksik durumdaki bu bölümde, 
hamile bir kadının kötü gezegen etkisinden uzak kalma amaçlı, Yétiken Sūtra’ya başvurup devamında kazanacă̆ fayda net bir şekilde görülmektedir.

\subsubsection{Meşalelerin/Kandillerin yakılacağı vakit}

Durrant'a göre, Budizm'de en iyi yemek ve içecekleri doğru zamanda fark edip bunları rahiplere sunma, sunu yapan kişinin yaşamını uzatan ve bu hayatı kaliteli duruma getiren işlevle sahiptir. Budizm'de meditasyona yardımcı roldeki sunular, kandil, tütsü, çiçekler ve büyülü sözlerdir. Bu uygulamalar, cömertlik erdemi ile çoğu zaman egoyu ortadan kaldıran yöne sahiptir. Buda'ya, kutsal bir varlığa ya da bir guru'ya sunular sunma, sahip olunan arzuya ulaşmaya niyetlenen aklın ve kalbin göstergesidir (2001: 8).

Kutsal varlıklara özellikle Buda niteliğine sahip kişilere tütsü ve kandiller sunma, Tantrik Budizm ile Taoizm’in uyuştuğu noktalardan biridir. Uygurca versiyonun bu bölümünde, ilgili ritüellerin son aşaması olarak yapılacak bu uygulamanın gerçekleşeceği ay ve gün hakkında bilgi verilmektedir.

BT XXIII G 305-320: yétikenke yula tamdurgu künlerig ayu bérelim : [a]ram ay yéti yayıka : ék[int]i ay tört yayıka : üçünç ay éki yayıka : törtünç ay yéti otuzka : béşinç ay béş otuzka : altınç ay üç otuzka : yétinç ay y(é)g(i)rmike : sekizinç ay yéti [y(é)g(i)rmike:] tokuzunç ay y(e)me [tört y(é)g(i)rmike:] onunç ay bir y(é)g(i)rmike : bir y(é)g(i)rminç ay béş y(é)g(i)rmike : ç(a)hşap(a)t ay sekiz yayıka : yula tamturgu künler tükedi : sadu : sadu : "Yétiken için meşale ya da kandillerin yakılacağı günleri söyleyelim: Birinci ayın yedisinde, ikinci ayın dördünde, üçüncü ayın ikisinde, dördüncü ayın yirmi yedisinde, beşinci ayın yirmi beşinde, altıncı ayın yirmi üçünde, yedinci ayın yirmisinde, sekizinci ayın on yedisinde, dokuzuncu ayın yirmisinde, onuncu ayın on birinde, on birinci ayın on beşinde ve on ikinci ayın sekizinde kandilleri yakmak gereklidir. Meşale ya da kandil yakılacak günler bitti: Kutlu olsun! Âmin!" (Zieme, 2005: 146).

Uygurca versiyonda, doğrudan Yétiken Takımyıldızı onuruna yapılacak ritüellerin son aşaması bu uygulamadır. Bu uygulama temelinde, önceki bölümlerde çeşitli başlıklarla gösterdiğimiz faydalara erişmek için son ritüel olan kandil ya da meşalelerin belli bir günde yakılması gerekmektedir. $\mathrm{Bu}$ yönüyle, hem Taoizm hem de Tantrik Budizm özelinde çalışmanın bu bölümü içerisinde gösterilen inanç türleri, Çin düşünce sistemi içerisinde yan yana yürüyen ve yayılmacı bir etki ile Orta Asya'ya ulaşan Taoist ve Tantrik fikirlerin karışımı ile oluşmuş bir inanç sistemini bizlere sunmaktadır.

\section{Sonuç}

Budist Uygurlar vasıtasıyla hakkında dinî yönden bilgi sahibi olduğumuz Yétiken Takımyıldızı inancı ile ilgili elde edilen sonuçlar şunlardır:

1. Büyükayı Takımyıldızı, bu yıldız grubunun bünyesinde barındırdığı Yedi Yıldız temelinde "yedi" sayısına dayanan birleşimlerle Türk düşünce sistemi içerisinde yazılı metinler yoluyla tanıklanmıştır. Tarihî metinler temelinde, Yétiken ve Yédiger gibi adlandırmalarla görülen bu takımyıldızı, Arapça ve Farsçanın etkisiyle İslamî görünümde, Arapça Dübbüekber, Benatı-na'ş Benatü’n-na'ş ve Farsça heftevreng ifadeleriyle Türk düşünce sistemi içerisinde yer almıştır.

2. Eski Türklerde Yétiken ismine karşılık gelen Büyükayı Takımyıldızı, Türk düşünce sistemi içerisinde din dışı bir görünümde daha çok göçebe Türklerin yaşamlarını vakit yönünden kolaylaştıran bir yıldız grubu olarak tanımlanmıştır. Budist Uygurların kültürel ve dinî ilişkilerle geliştirdikleri anlayışla Çin 
düşünce sisteminden Türk dinî yaşamına uyarlanan Yétiken Takımyıldızı, Uygurlarda Yétiken Sūtra olarak bilinen dinî esere konu olmuştur.

3. Yétiken Sūtra temelli incelemeler, ilgili metin tanıklı̆̆nda yer alan dinî ögelerin Taoist ve Tantrik etkilere sahip olduğunu göstermiştir. Metinde yer alan dinî ögelerin Çin Ezoterik Budizmi temelinde Uygurlarda da aynı etkileri gösterdiği anlaşılmıştır. Bu etkiler, takımyıldızlara ilahlık yükleme, muskalar, Yıldız Tanrılara yakarış, Buda ve Bodisattva kişilikleri özelinde ilgili ritüelleri hızlandırma, büyülü sözler kullanma gibi inanç uygulamalarını göstermektedir. Bu ritüeller yoluyla, çeşitli faydalara ulaşma, Taoizm ve Tantrik Budizm temelli Çin Budizmi bünyesinde yer alan karışımları göstermesi bakımından Taoizm ve Tantrik Budizm’in aynı amaçlara sahip olduğunu göstermektedir. Bu benzerlikler, Taoizm ve Tantrik Budizm'in Çin toplumu içerisinde aynı dönemde gelişim bulmasından ileri gelmektedir. Bu yönüyle, eldeki çalışmada gösterilen dinî uygulamalar ve elde edilecek faydalar, Budist Uygurlar özelinde Yétiken kültünün yaşanılan dönem açısından popüler olduğunu göstermektedir.

\section{Kisaltmalar}

$\begin{array}{ll}\text { BT XXIII } & \text { Berliner Turfantexte XXIII. } \\ \text { Çev. } & \text { Çeviren. } \\ \text { Ed. } & \text { Editör. } \\ \text { T } & \text { Taishō Tripitaka. } \\ \text { TS } & \text { Tarama Sözlüğ̈̈. } \\ \text { TT VII } & \text { Türkische Turfan Texte VII. } \\ \text { vd. } & \text { ve diğerleri. }\end{array}$

\section{Kaynaklar}

Altaylı, S. (1994). Azerbaycan Türkçesi sözlüğü II. İstanbul: MEB.

Arat, R. R. ve Eberhard, W. (1936). Türkische Turfan Texte VII. Berlin: ABAW.

Atwood, C. P. (2004). Encyclopedia of Mongolia and the Mongol Empire. New York: Facts On File.

Bayat, F. (2017). Türk Mitolojik sistemi 1 ontolojik ve epistemolojik bağlamda Türk Mitolojisi. İstanbul: Ötüken.

Bayram, B. (2017). Çuvaş Türkçesi-Türkiye Türkçesi sözlük. Konya: Tablet.

Bazin, L. (1963). Über die sternkunde in alttürkischer Zeit. Wiesbaden: Akademie der Wissenschaften und der Literatur. 571-582.

Buswell, R. E. (2004). Encyplopedia of Buddhism. New York: Thomsen Gale.

Buswell, R. E. ve Lopez, D. S. (2014). The Princeton dictionary of Buddhism. Princeton: Princeton University Press.

Capitanio, J. (2011). Esoteric Buddhist elements In Daoist ritual manuals of the Song, Yuan and Ming. Ed. C. D. Orzech. Esoteric Buddhism and the Tantras in East Asia içinde (ss. 529-536). Handbook of Oriental Studies, Section 4 (China), 24, Leiden: Brill.

Chiang, P. (2016). Models in Taoist liturgical texts: typology, transmission and Usage A case study of the Guangcheng yizhi and the Guangcheng tradition in modern Sichuan. Doktora Tezi. Fransa.

Copp, P. (2011). Esoteric Buddhism in Song Dynasty Sichuan. Ed. C. D. Orzech. Esoteric Buddhism and the Tantras in East Asia içinde (ss. 431-434) Handbook of Oriental Studies, Section 4 (China), 24. Leiden: Brill. 
Durrant, B. (2001). Buddhist rituals \& observances. Amaravati Publications.

Ehmetyanov, R. vd. (2014). Türkçe-Tatarca sözlük. Çev. Mustafa Öner. Ankara: TDK.

Elverskog, J. (1997). Uygur Buddhist literature. Silk Road Studies I. Brepols.

Franke, H.(1990). The Taoist elements in the Buddhist Great Bear Sūtra (Pei-tou ching). Asia Major III: 75-111.

Gültepe, N. (2017). Türk Mitolojisi yeni araştırmalar ışı̆̆ında. İstanbul: Kapı.

Gürsoy Naskali, E. ve Duranl,, M. (1999). Altayca-Türkçe sözlük. Ankara: TDK.

Heissig, W.(1980). The Religions of Mongolia. Çev. Geoffrey Samuel. Berkeley-Los Angeles-California: University of California Press.

Hidas, G. (2015). Dhāraṇī Sūtras. Ed. J. Silk, O. von Hinüber ve V. Eltschinger. Brill's Encyclopedia of Buddhism içinde (ss. 129-137). Vol. I. Literature and Languages. Leiden: Brill.

Irons, E. A. (2008). Encyclopedia of Buddhism. New York: Facts On File.

Jing, A. (1991). The Yuan Buddhist mural of the paradise of Bhaiśajyaguru. The Metropolitan Museum of Art, 26: 147-166.

Judachin, K. K. (1965). Kirgizsko-Russkiy slovar. Moskova.

Keown, D. (2003). Dictionary of Buddhism. Newyork: Oxford University Press.

Keyworth, G. A. (2016). Apocryphal Chinese books in the Buddhist canon at Matsuo Shintō shrine. Studies in Chinese Religions 2(3):1-34.

Koç, K., vd. (2013). Kazak Türkçesi Türkiye Türkçesi sözlüğü. Ankara: Akçağ.

Kotyk, J. (2018). Japanese Buddhist astrology and astral magic Mikkyō and Sukuyōdō. Japanese Journal of Religious Studies, 45: 37-86.

Li, Y. S. (2014). Some star in modern Turkic languages-II. Belleten 62-2: 157-202.

Ligeti, L. (1967). Doluyan ebügen neretü odun-u sudur. Mongol Nyelvemléktár V Preklasszikus emlékek 3. Jüan-és Ming-kori emlékek klasszikus átírásban içinde (ss. 103-114). Budapeşte.

McBride II, R. D. (2011). Popular Esoteric Deities And the spread of their cults. Ed. C. D. Orzech. Esoteric Buddhism and the Tantras in East Asia içinde (ss. 129-137). Handbook of Oriental Studies, Section 4 (China), 24, Leiden: Brill.

Mollier, C. (2008). Buddhism and Taoism face to face scripture, ritual and ıconographic exchange in Medieval China. USA: Hawai'i Press.

Nadžip, Ė. N. (1968). Uygursko-Russkiy slovar. Moskova.

Özşahin, M. (2017). Başkurt Türkçesi sözlüğü. Ankara: TDK.

Payne, R. K. (2016). The Homa of the Northern Dipper. Ed. David Gray ve Ryan Richard Overbey. Tantric traditions in transmission and translation içinde (ss. 284-307). UK: Oxford University Press.

Pekarskiy, E. K. (1958). Slovar Yakutskogo yazyka I. Moskova.

Potopov, L. P. ve Menges, K. H. (1934). Materialen zur volkskunde Türkvölkern. MSOS 37: 165-168.

Pregadio, F. (2008). The encyclopedia of Taoism A-Z. London-New York: Routledge.

Robson, J. (2008). Signs of power: Talismanic writing in Chinese Buddhism. History of Religions 48 (2): $130-139$.

Robson, J.(2011). Talismans In Chinese Ezoteric Buddhism. Ed. C. D. Orzech. Esoteric Buddhism and the Tantras in East Asia içinde (ss. 225-229). Handbook of Oriental Studies, Section 4 (China), 24, Leiden: Brill. 
Silk, J. A. (2019). Chinese sūtras in Tibetan Translation a preliminary survey. Annual Report of the International Research Institue for Advanced Buddhology (ARIRIAB). XXII: 227-246.

Skvortsov, M. İ. (1982). Çuvaşssko-Russkiy slovar. Ekonimiki Pri Sovyete Ministrov Çu. ASSR.

Sørensen, H. H. (2011a). Astrology and the worship of the planets In Esoteric Buddhism of the Tang. Ed. C. D. Orzech. Esoteric Buddhism and the Tantras in East Asia içinde (ss. 230-244). Handbook of Oriental Studies, Section 4 (China), 24, Leiden: Brill.

Sørensen, H. H. (2011b). On Esoteric Buddhism In China: A working definition. Ed. C. D. Orzech. Esoteric Buddhism and the Tantras in East Asia içinde (ss. 155-175). Handbook of Oriental Studies, Section 4 (China), 24, Leiden: Brill.

Teiser, S. H. (1996). The spirits of Chinese religion. Ed. Donald S. Lopez. Religions of China in Practice içinde (ss. 1-33). USA: Princeton University Press.

Tekin, T., vd. (2018). Türkmence-Türkçe sözlük (1995). Ankara: Türk Dilleri Araştırmaları Dizisi: 18.

Türkçe sözlük (2005). Ankara: TDK.

Uyg்urçe-Henzuçe luġet (1974). Ürümçi: Şinciay Helk Neşriyati.

Wallace, V. A. (2015). Local literatures: Mongolia. Ed. Jonathan A. Silk. Brill's Encyclopedia of Buddhism içinde (ss. 883-892). Leiden-Boston: Brill. 883-892.

Wilkens, J. (2011). Hatten die alten uiguren einen buddhistischen Kanon?. Ed. Max Deeg, Oliver Freiberger ve Christoph Kleine. Kanonisierung und Kanonbildung in der asiatischen Religionsgeschichte içinde (ss. 345-378). Wien: Verlag der Osterreichischen Akademie der Wissenschaften.

Yakup, A. (2008). Die uigurischen blockdrucke der Berliner Turfansammlung, Teil 2: Apokryphen, Mahāyāna-Sūtren, Erzählungen, Magısche Texte, Kommentare und Kolophone, Alttürkische Handschriften Teil 12. Verzeichnis Der Orientalischen Handschriften In Deutschland Band XIII, 20. Stutgart: Franz Steiner Verlag.

Yengel, Ş. (2018). Türk medeniyetlerinde astroloji astronomi ve müneccimlik. İstanbul: İnkılâp.

Zieme, P. (1994). Hatte der Große Bär bei den Uiguren neun Sterne? . Ed. K. Röhrborn ve W. Veenker. Memoriae munusculum. Gedenkband für Annemarie v. Gabain içinde (ss. 149-154). Wiesbaden.

Zieme, P. (2005). Magische texte des uigurischen Buddhismus. Berliner Turfantexte XXIII. Turnhout: Brepols.

XIII. yüzyıldan beri Türkiye Türkçesiyle yazılmış kitaplardan toplanan tanıklarıyla Tarama Sözlüğü VI $U-Z$ (2009). Ankara: TDK.

\section{İnternet kaynakları}

http://aven.amritalearning.com/index.php?sub=101\&brch=299\&sim=1515\&cnt=3513 (Erişim Tarihi: 14.07.2020).

https://www.bbc.co.uk/religion/religions/taoism/rites/rites.shtml (Erişim Tarihi: 14.07.2020).

https://www.britannica.com/place/Ursa-Major (Erişim Tarihi: 14.07.2020).

http://www.futura-sciences.us/dico/d/space-constellation-ursa-major-50005604/(Erişim Tarihi: 14.07.2020).

http://www.okinoshima-heritage.jp/files/ReportDetail_79_file.pdf (Erişim Tarihi: 14.07.2020).

https://osr.org/tr/takimyildizi/ursa-major/ (Erişim Tarihi: 14.07.2020).

https://21dzk.l.u-tokyo.ac.jp/SAT/satdb2015.php?lang=en (Erişim Tarihi: 14.07.2020).

https://thenewkorea.wordpress.com/2015/09/17/the-seven-stars-of-the-north-5/(Erişim 14.07.2020).

Tarihi: 
224 / RumeliDE Journal of Language and Literature Studies 2020.S7 (October)

The Yétiken Constellation belief in Buddhist Uyghurs / H. İsi (pp. 206-223)

Adres | Address

Kırklareli Üniversitesi, Fen Edebiyat Fakültesi, Türk Dili ve Edebiyatı Kırklareli University, Faculty of Arts and Sciences, Department of Bölümü, Kayalı Kampüsü-Kırklareli/TÜRKIYY $\quad$ Turkish Language and Literature, Kayalı Campus-Kırklareli/TURKEY

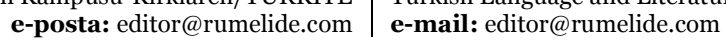

